\title{
Fides quaerens intellectum: o fundamento da teologia e a teologia fundamental na esfera públiea
}

\section{Fides quaerens intellectum: the foundation of the- ology and fundamental theology in public sphere}

\section{Thiago De Moliner Eufrásio* \\ Tiago de Fraga Gomes**}

Recebido: 16/08/2017. Aprovado: 13/11/208.

Resumo: A fé procura sua inteligência em dois movimentos: um ad extra, compreendendo o que se passa ao seu redor e um ad intra, num movimento de autoconsciência. Fides quaerens intellectum evoca, em dias marcados pela pluralidade e secularização, o fundamento da própria teologia. A teologia fundamental é uma zona de fronteira entre a teologia e o mundo, a fim de traduzir as questões da fé para a linguagem atual, deixando de lado uma atitude apologética de autodefesa em prol de uma postura dialógica de empatia e alteridade, na perspectiva do Vaticano II. A questão central da teologia fundamental é dar razões esclarecedoras da fé na esfera pública, enquanto dimensão reflexiva e operante dos fundamentos da fé diante da sociedade. A teologia é pública não apenas em sua autocompreensão, mas, sobretudo, enquanto ressalta a perspectiva escatológica das coisas públicas. É pública a partir de uma visão crítica dos problemas sociais, a fim de contribuir com a cidadania e de pensar em uma sociedade que proporcione um projeto de vida mais integral e humanizado, na perspectiva do Reinado de Deus.

Palavras-chave: Inteligência da fé. Pluralismo. Secularização. Fundamento da teologia. Teologia fundamental. Teologia pública.

Abstract: Faith seeks its intelligence in two movements: an extra ad, understanding what is going on around it and an ad intra, in a movement of self-

Mestre em Teologia Sistemática (PUCRS, Porto Alegre, 2016). Doutorando em Teologia Sistemática, PUCRS. Bolsista da CAPES.

E-mail: theufrasio@hotmail.com.

** Mestre em Teologia Sistemática (PUCRS, Porto Alegre, 2015). Doutorando em Teologia Sistemática, PUCRS. Bolsista da CAPES.

E-mail: tiago_mail@yahoo.com.br. 
-consciousness. Fides quaerens intellectum evokes, in days marked by plurality and secularization, the foundation of theology itself. Fundamental theology is a frontier zone between theology and the world, in order to translate the questions of faith into current language, leaving aside an apologetic attitude of self-defense in favor of a dialogical posture of empathy and otherness, along the perspective of Vatican II. The central question of fundamental theology is to give illuminating reasons for faith in the public sphere as a reflective and operative dimension of the foundations of faith before society. Theology is public not only in its self-understanding, but above all, as it emphasizes the eschatological perspective of public affairs. It's public from a critical view of social problems, in order to contribute to citizenship and to think of a society that provides a project of life more integral and humanized, in the perspective of the Reign of God.

Keywords: Intelligence of faith. Pluralism. Secularization. Foundations of theology. Fundamental theology. Public theology.

\section{Introdução}

O título parece um jogo de palavras. Mais do que isso, ele pretende indicar o percurso da fé que procura compreender-se e compreender sua realidade. A fé que procura sua inteligência o faz em dois movimentos: um ad extra, para fora, compreendendo o que se passa ao seu redor e um ad intra, sobre si mesmo, num movimento de autoconsciência. Dois momentos que, embora distintos, se complementam formando uma unidade. A fé procura uma razão e, ao mesmo tempo, possui sua ratio. A expressão da carta de Pedro, "estando sempre prontos a dar razão da vossa esperança" $(1 \mathrm{Pd} 3,15)$, indica esse sentido.

Não há uma fé fora de contexto; a rigor, não há um contexto em que ela não possa expressar-se. Fé e contexto se interpenetram em movimento performativo. O ponto de partida, portanto, não é apenas o fundamento da teologia ou a teologia fundamental como realidades curvadas sobre si mesmas, mas o contexto que a comporta - elemento capaz de sincronizar e explicitar estes dois aspectos. A teologia deve levar a sério o Sitz im leben (lugar na vida) onde é formulada, pois toda teologia é contextual ${ }^{1}$. No contexto, o ser humano acolhe o dom da fé, que o capacita, de modo esponsal, a uma realidade que está além dele, e, ao mesmo tempo, o abraça, significando-o.

1 CALDAS, Carlos. Desafios da teologia pública para a reflexão teológica na América Latina. Revista de Cultura Teológica, São Paulo, v. 88, p. 328-353, jul./dez. 2016, p. 330. 
Observar a fé sob este ponto de vista traduz a esperança cristã, que se realiza radicalmente na glorificação do Verbo. Isso indica que o dado principal da fé comunica-se como doação e não como produção pretensiosa e absoluta do homo faber. Neste sentido, fé e esperança dão-se as mãos. O que na fé é Aliança e fidelidade, na esperança é anseio e horizonte. Em ambas, a caridade reina como mãe de muitos filhos e generosa doadora de uma realidade que nela é permanente.

Este sentido não é mais tão evidente como nos tempos de uma sociedade predominantemente cristã. Todavia, para um cristão ela é, ou ao menos deveria ser, fundamento de vida, pois, como dito acima, orienta-se ao sentido último da vida realizado em Cristo. A menos que a crítica de Mounier sobre a banalidade do ser cristão no final da década de 1940, seja relida hoje como uma profecia. Diz ele, "torna-se cristão "como se calçam meias' da maneira mais prazerosa do mundo"2.

O que se pretende afirmar, portanto, é que o entendimento último da fé manifesta o sentido radical da vida a um sujeito histórico marcado, sobretudo, por este anseio: a busca de um sentido pleno para a vida. Uma questão que não há como desvencilhar-se: seja pela sustentação ou pela negação dele, declinando um modus vivendi, uma opção fundamental. Aqui, as questões levantadas por Kant permanecem atuais: "o que posso saber? O que devo fazer? O que posso esperar?"’3. E adentrando nas problemáticas pertinentes ao contexto da modernidade tardia, é legítimo perguntar: "como trabalhar a inteligência da fé em um contexto extremamente secularizado e dominado pela racionalidade científica e instrumental?" ${ }^{2}$. Mais do que nunca, a teologia deve buscar respostas às indagações da inquietude humana.

\section{A revelação de deus como fundamento da teologia}

Fides quaerens intellectum, afirmou Santo Anselmo. O que evoca esta afirmação em dias marcados pela pluralidade e secularização? Segundo Clodovis Boff, esta expressão foi o primeiro nome da obra

2 MOUNIER, Emmanuel. Quando a cristandade morre. Rio de Janeiro: Paz e Terra, 1972. p. 202.

3 KANT apud ALFARO, Juan. De la cuestión del Hombre a la cuestión de Dios. Salamanca: Sigueme, 1989. p. 29.

4 GOMES, Tiago de Fraga. Por uma relação entre inteligência da fé e racionalidade científica no contexto atual. Encontros Teológicos, Florianópolis, v. 32, n. 1, p. 121138, jan./abr. 2017, p. 122. 
Proslogion de Santo Anselmo ${ }^{5}$. Tal expressão "situa-se na linha de Santo Agostinho, que havia dito: 'desejei ver com a inteligência o que acreditei'. Há, portanto, na fé uma "vontade de verdade" "'. Observa-se, pois, que o exercício teológico, situa-se no horizonte humano que busca sentido, buscando-se além de si mesmo.

No pensamento de Santo Agostinho que inspirou Santo Anselmo, Boff percebe a relação entre a fé e a verdade, que aponta para a coerência. Neste sentido, se pode dizer que ela carrega em si uma força vital e significante. E isso o leva à conclusão de que "a inteligência da fé é, no fundo, experiência. É sapiência. É contemplação. A inteligência da fé é a capacidade de reconhecer a preeminência do Amor sobre quaisquer outras razões"7. Todos estes elementos inspiram sentido.

A pluralidade e as crises de linguagem que o cristianismo tem vivido, o colocam diante do desafio de comunicar plausivelmente seu conteúdo. Crises não somente de linguagem, mas também de respaldo ${ }^{8}$. É o que constataram os bispos na Conferência de Aparecida:

Sem dúvida, as situações de injustiça e pobreza extrema são um sinal acusador de que a fé não teve a força necessária para penetrar os critérios e as decisões dos setores responsáveis da liderança ideológica e da organização da convivência social e econômica de nossos povos. Em povos de arraigada fé cristã impuseram-se estruturas geradoras de injustiça (DAp 437).

Ironicamente, talvez se possa dizer, este é o diagnóstico feito no maior continente cristão do mundo. Constatação que enfraquece o respaldo do anúncio cristão, refletindo, não de modo isolado, o que Bernhard Grümme observa:

O cristianismo institucionalizado entra numa crise que tem a ver com os processos da ruptura de tradição, a perda da institucionalização de ambientes tradicionais, com a liberação de vínculos tradicionais, a individualização, a secularização e pluralização ${ }^{9}$.

5 BOFF, Clodovis. Teoria do método teológico. São Paulo: Vozes, 1998. p. 25.

$6 \quad$ lb. p. 25.

7 lb. p. 68.

8 LIBANIO, João Batista. Eu creio nós cremos: tratado da fé. São Paulo: Loyola, 2000. p. 34.

9 GRÜMME, Bernhard. Uma época sem religião: pluralismo e secularização. Subsídios do Seminário Intensivo de Teologia Pública. Porto Alegre: PUCRS, 2017c. p. 4. 
Estes elementos despertam para a questão desafiadora que o cristianismo tem diante de si: como manter, de modo plausível, a singularidade e a relevância da fé cristã num contexto tão plural e relativo? Que cristianismo para que ser humano? Afinal, se muda o contexto, a compressão de história, de mundo e de ser humano, não se pode esperar que a manifestação da fé permaneça com os mesmos contornos.

O dado fundante da teologia cristã é a Revelação. A Constituição Dogmática Dei Verbum ao versar sobre ela, justifica-a como iniciativa de Deus que, revelando-se a si mesmo, torna conhecida sua vontade. Por meio dela, diz o Concílio Vaticano II, os "homens por Cristo, Verbo feito carne, no Espírito Santo tem acesso ao Pai e se tornam participantes da natureza divina" (DV 2). Tal afirmação implica na compreensão de que o fundamento da teologia é a própria revelação de Deus que comporta a vocação última do ser humano, pois "Deus se doa a si mesmo em sua vontade salvífica universal, que quer a plenificação de todos os seres humanos e de toda criação"10.

O fundamento da teologia é, portanto, a autocomunicação de Deus. Diz Jesus no Evangelho de João: "Se alguém me ama, guardará minha palavra e meu Pai o amará e a ele viremos e nele estabeleceremos morada" (Jo 14,23). No caso da teologia católica, essa manifestação está, por excelência, em dois lugares teológicos: a Tradição e a Sagrada Escritura. Vale observar que esta declaração do Concílio Vaticano II reafirma o que já havia sido declarado na IV sessão do Concílio de Trento. Não se trata de duas fontes, mas de uma que se desdobra em dois aspectos. Assim se pode ler:

Vendo claramente que essa verdade e essa ordem [Evangelho] estão contidas em livros escritos e tradições não escritas que, recebidas pelos próprios Apóstolos da boca do próprio Cristo ou transmitidas como que de mão em mão pelos Apóstolos, sob o ditado do Espírito Santo, chegaram até nós (DH 1501).

Ambas, Tradição e Escritura, como braços de um único rio, levam consigo não apenas o que brota da fonte, mas, em certa medida, a própria fonte. Na Dei Verbum se pode ler: "A Sagrada Tradição e a Sagrada Escritura [...] promanam da mesma nascente divina, formam de certo

10 ID. Religião e fé como realização do ser humano: aproximações antropológicas nas condições da modernidade tardia. Subsídios do Seminário Intensivo de Teologia Pública. Porto Alegre: PUCRS, 2017d. p.15. 
modo um só todo e tendem para o mesmo fim" (DV 9). Assim, considerando o conteúdo da Revelação na Tradição e na Sagrada Escritura, a pergunta que se levanta é: que implicação tem dizer que de ambas flui a autocomunicação de Deus?

A Escritura assim afirma: "Deus é amor." (1Jo 4,8). Se pode dizer, inicialmente, que o conteúdo da Revelação, isto é, a autocomunicação de Deus, é o amor. Retomando a afirmação da Dei Verbum 2, pode-se concluir que a participação na vida divina é participação no amor, um amor que, mergulhando no mais profundo abismo da imanência, transcende o amado (ser humano) à sua plenitude, pois tão forte como a morte é o amor $(\mathrm{Ct} 8,6)$.

Se a Revelação fosse apenas algo sobre Deus, algo externo a Ele mesmo, tal conteúdo correria o risco de cair no deísmo como fora pensado por Kant: uma esperança para além da esperança, que até alimenta o caminho, mas não implica na presença de um Totalmente Outro. Juan Alfaro, comentando esta compreensão kantiana expressou:

Uma vida nova mais além da morte não nos é acessivel através de uma reflexão sobre a simplicidade de uma substância espiritual (alma), mas unicamente como término do esperar humano, sempre aberto a um mais de plenitude que o homem não pode por si mesmo lograr nem "saber" previamente de que modo virá11.

Por isso, é importante também retomar a Dei Verbum 9, onde se lê que a Escritura e a Tradição são oriundas da mesma fonte, fazem o mesmo caminho e chegam ao mesmo destino. Noutras palavras: o eterno não só se deu a conhecer, mas entrou no tempo. $\mathrm{O}$ amor se fez temporal. No Verbo encarnado, a Palavra se fez Tradição, mergulhou na história, contextualizou-se. De um modo radical: o Verbo secularizou-se. Ao entrar no tempo, o amor se faz um de nós. E aqui, tem-se um paradoxo: ao revelar-se, Deus se esconde entre os seres humanos fazendo-se um deles.

A tese da unidade do amor a Deus e ao próximo chama de forma insistente atenção sobre esse fato. Deus é recusado ai onde se rechaça e difama o próximo, Deus é historicamente aceito e levado a tornado verdadeiro onde existe atenção de amor e respeito ao outro. A relação originária e própria a Deus é o amor ao próximo ${ }^{12}$.

11 ALFARO, Juan. De la cuestión del Hombre a la cuestión de Dios. Salamanca: Sigueme, 1989. p. 32.

12 GRÜMME, Bernhard. Um conceito não-simultâneo da liberdade: liberdade liberada. Subsídios do Seminário Intensivo de Teologia Pública. Porto Alegre: PUCRS, 2017b. p. 14. 
A Revelação de Deus é ao mesmo tempo seu escondimento. Sua permanência levanta uma grande alegria e também uma grande inquietação que em termos práticos poderia ser condensada no assombro: e se for ele? Deste modo, os desdobramentos da autocomunicação do Amor se estendem historicamente nos semblantes anônimos que se tornam um Tu pessoal. E aqui, a narrativa de Mateus 25 não deixa margem para outra possibilidade senão a de considerar, sempre, esta possibilidade do Deus que se revela na alteridade mais radical.

\section{A teologia fundamental e o ser humano como fronteira e ponto de unidade}

É importante retomar aqui a citação da carta de Pedro: "Estando sempre prontos a dar razão da vossa esperança" (1Pd 3,15), acrescentando, todavia, o modo como deve ser dada tal razão: "fazei-o, porém, com mansidão e respeito, conservando a vossa boa consciência" (1Pd 3,16a). Recomendação que depois é acrescida de justificativas e motivações (1Pd 3,16b-17). Mansidão, respeito e boa consciência: elementos para uma apologética que leva em conta o diálogo, a alteridade. Retirar do cristianismo a dimensão apologética, é tirar seu elã, enquanto se entende por apologética a manifestação e justificação da esperança.

A fé e a teologia são contextuais. "Estão situadas em contexto cultural como social, político e econômico, bem como epistemologicamente quanto sociologicamente. O teólogo Johann Batist Metz, certa vez definiu a teologia como a reflexão da fé em nosso tempo"13. Isso implica na consideração de que a teologia fundamental precisará encontrar também no ser humano uma justificativa, caso pretenda sustentar que a Revelação de Deus é sua autocomunicação ao ser humano, e que esta é um convite à vida divina. Trata-se, pois, de uma justificativa que torne razoável a afirmação de que a autocomunicação de Deus responde aos anseios mais profundos do ser humano no que diz respeito a sua auto-realização que coaduna no amor e na liberdade.

Retomando a analogia da nascente que se tornando rio tem seus dois braços (Tradição e Escritura), se pode dar um passo a mais e dizer que o leito deste rio é a humanidade e suas margens são os contextos

13 ID. Fé impossível?: questionamentos das ciências, da economia, da sociedade e da cultura. Subsídios do Seminário Intensivo de Teologia Pública. Porto Alegre: PUCRS, 2017a. p. 1. 
históricos. Margens que vão dando ao leito sua forma, ao mesmo tempo, que se reconfiguram com a força das águas (Revelação) que correm não sobre o leito, mas no leito.

Em cada cristão, a história sagrada e a história profana se encontram e manifestam o sentido último da história secular, isto é, ser sacramento da eternidade. Na história secular, a história sagrada e a profana se entrelaçam. Em perspectiva cristológica, "isto representa a abrangência do dogma de Calcedônia, segundo o qual Deus e o ser humano em Jesus Cristo estão vinculados inseparavelmente e sem mistura"14. E é nessa dimensão temporal que Emmanuel Mounier compõe o axioma: "sempre atual em sua essência, o cristianismo nunca está atualizado"15. A Gaudium et Spes também transparece essa ideia quando afirma:

As alegrias e as esperanças, as tristezas e as angústias dos homens de hoje, sobretudo dos pobres e de todos aqueles que sofrem, são também as alegrias e as esperanças, as tristezas e as angústias dos discípulos de Cristo; e não há realidade alguma verdadeiramente humana que não encontre eco no seu coração [...] Por este motivo, a Igreja sente-se real e intimamente ligada ao gênero humano e à sua história (GS 1).

Estes elementos indicam a questão da teologia fundamental que se coloca na fronteira, ou seja, em contato direto com outras ciências. Se por fronteira entende-se o lugar comum do encontro de diferentes realidades, ela não é senão o próprio ser humano. Nele, diferentes realidades, perspectivas e horizontes se encontram. No ser humano, o aspecto comum daquilo que é mais diverso se faz perceber: a busca pelo sentido. Uma fronteira que distingue para unir.

$\mathrm{Na}$ fronteira se torna ainda mais claro o desafio da teologia que não esta mais num contexto onde se supõe a fé cristã, mas onde se afirma o pluralismo. Tal pluralismo, diz Grümme, que gera uma espécie de agnosticismo prático pode ser diagnosticado nos seguintes termos: "se a religião é verdadeira ou não, não está em questão e é secundário. No entanto, possui sempre um significado em articulações centrais da própria vida" ${ }^{16}$. O pluralismo atual eclipsou o respaldo da exclusiva

14 ID. Um conceito não-simultâneo da liberdade: liberdade liberada. Subsídios do Seminário Intensivo de Teologia Pública. Porto Alegre: PUCRS, 2017b. p. 15.

15 MOUNIER, Emmanuel. Quando a cristandade morre. Rio de Janeiro: Paz e Terra, 1972. p. 213.

16 GRÜMME, Bernhard. Uma época sem religião: pluralismo e secularização. Subsídios do Seminário Intensivo de Teologia Pública. Porto Alegre: PUCRS, 2017c. p. 13. 
cidadania cristã, e iluminou um horizonte marcado pela presença de diferentes tradições religiosas e correntes espirituais. Neste cenário, o axioma de Mounier citado acima, mostra a vitalidade e o desafio da fé cristã. O desafio se agudiza se for considerar o condicional proposto por Juan Alfaro:

A resposta à questão do sentido há que buscá-la em primeiro lugar dentro da realidade intramundana total, constituida pela relação homem-mundo-história. Se a resposta última à questão do sentido se encontrará dentro do real intramundano, não haveria que buscar ulteriormente: não se daria a questão de Deus. Somente se as respostas possiveis que oferecem o intramundano não são últimas, mas que por si mesmas exigem perguntar mais além de todas elas, haverá que colocar a questão do Transcendente, Último, Incondicionado ${ }^{17}$.

A essência da fé cristã é seu ingresso significante na história e não sua automanutenção. O retorno à cristandade, mais preocupado com seus conteúdos do que com seu aprofundamento, é algo agonizante, senão superado. A ilusão de estar numa sociedade cristã, aos moldes da cristandade, é ir do nada a lugar algum. O fato é que o pluralismo tem tido a sã tarefa de despertar o cristianismo à necessidade de sua atualização na esfera pública, deixando-se questionar dialeticamente. Neste questionar, suas proposições poderão ser ouvidas, do contrário, corre o risco de falar a si mesmo.

Portanto, pode-se dizer que a saída para o cristianismo está na compreensão de que ele precisa recomeçar a cada geração - um constante aggiornamento. Noutras palavras, é o desafio proposto por São João XXIII ao inaugurar o Concílio Vaticano II para quem a Igreja não deve se apartar "do patrimônio sagrado da verdade [...] e, ao mesmo tempo, deve também olhar para o presente, para as novas condições e formas de vida introduzidas no mundo hodierno, que abriram novos caminhos ao apostolado católico" ${ }^{18}$. Isso não significa negar sua Tradição milenar, mas, outrossim, perceber que os contextos históricos são tão diversos que sem uma inculturação estarão fadados ao isolamento.

17 ALFARO, Juan. De la cuestión del Hombre a la cuestión de Dios. Salamanca: Sigueme, 1989. p. 28.

18 JOÃO XXIII, Papa. Discurso de Sua Santidade Papa João XXIII na Abertura Solene do Ss. Concílio, Roma, 1962. Disponível em: <https://w2.vatican.va/content/john-xxiii/ pt/speeches/1962/documents/hf_j-xxiii_spe_19621011_opening-council.html>. Acesso em: 30 maio 2017. 


\section{A teologia fundamental na esfera pública}

Perante o que fora exposto acima, pode-se dizer que a teologia fundamental é a soleira da teologia para a sociedade, tendo o ser humano como foco de sua atenção. Faz isto se ocupando com questões filosóficas e científicas, a fim de traduzir as questões da fé para a linguagem atual. Deste modo, o exercício teológico deixa de lado a atitude apologética de autodefesa em prol de uma postura dialógica e empática, a partir do princípio de que "a fé nos liberta do isolamento e nos conduz à comunhão"19. Nesse sentido, se pode afirmar que "teologia é saber construído em diálogo"20.

No horizonte da teologia sistemática, a teologia fundamental e a teologia dogmática precisam estar sempre interligadas, pois só é possível entender profundamente a fé cristã e comunicá-la se esta estiver conectada com as inquietações do mundo de hoje. Mais do que apenas demonstrar as verdades de fé, faz-se necessário fundamentá-las, indicando também sua relevância, de tal forma que mesmo quem não crê ou crê de modo diverso, perceba seu sentido, significado e pertinência para a sociedade hodierna. Por isso, a tarefa do teólogo fundamental é, sobretudo, dialogar com a sociedade secular e pluralista, trazendo consigo o específico da tradição cristã.

Por outro lado, é preciso cuidar também que não sejam as verdades religiosas a influenciar apologeticamente as deliberações institucionais do Estado $^{21}$. A teologia pública diz respeito às contribuições da teologia na esfera pública, com o intuito de exercer o direito e o dever à cidadania. "O sentimento religioso deveria ser traduzido em práticas de civilidade, tendo em vista de que o próprio Jesus exerceu seu ministério para além do templo"22. A teologia tem, nesse sentido, um caráter religioso e político.

19 GOMES, Tiago de Fraga. A eclesiologia conciliar na América Latina: a comunhão gera a missão. Porto Alegre: Editora Fi, 2015a. p. 66.

20 CALDAS, Carlos. Desafios da teologia pública para a reflexão teológica na América Latina. Revista de Cultura Teológica, São Paulo, v. 88, p. 328-353, jul./dez. 2016, p. 331.

21 CARVALHO, Osiel Lourenço de. Religiões no espaço público: reflexões a partir da teologia pública. Correlatio, São Paulo, v. 13, n. 25, p. 105-116, jun. 2014, p. 107.

22 lb., p. 108. 
Segundo o paradigma weberiano da secularização, a modernidade se encarregaria ela própria de relegar a religião à esfera privada dos indivíduos, tornando o Estado e a sociedade menos acessíveis aos processos de moralização religiosa. Porém, o que se percebe é cada vez mais uma presença significativa da religião na esfera pública. Nela, as diversas organizações sociais, incluindo as religiosas, têm uma função a desempenhar ${ }^{23}$.

Estes aspectos indicam que a esfera pública, enquanto rede para comunicação de conteúdos, opiniões e tomadas de posições, manifesta o agir comunicativo ${ }^{24}$. Segundo este paradigma habermasiano que supera o weberiano, a sociedade atual, marcada pelo pós-secularismo, não deve apenas aceitar as religiões ou tampouco relegá-las, mas reconhecê-las como instituições que exercem funções sociais positivas. Entretanto, para que isso aconteça, a linguagem religiosa precisa ser traduzida para um modo de compreensão que seja acessível a todos.

Nesta perspectiva, segundo Rudolf von Sinner, a teologia pública é uma resposta "aos desafios concretos da atualidade em diálogo com o que lhe é próprio: a tradição cristã" 25 . E para David Tracy, a teologia enquanto reflexão da fé pode ser caracterizada como um discurso público que tem como interlocutores privilegiados a tradição eclesial, a racionalidade acadêmica e a sociedade contemporânea ${ }^{26}$, tendo em vista os desafios emergentes do tempo atual.

Deve-se ter presente, portanto, que cada localização contextual promove na teologia algumas afinidades eletivas. Nesse sentido, a teologia fundamental dialoga e procura iluminar os anseios da sociedade, enquanto que a teologia dogmática foca, sobretudo, na elaboração academia dos conteúdos da fé, e a teologia prática busca contemplar as necessidades da comunidade eclesial. Embora, pedagogicamente se possa fazer esta tripartição, é preciso sublinhar que, toda teologia "é ontologicamente pública, não importa a qual público se dirija"27. A

$23 \quad$ lb., p. 106.

24 HABERMAS, Jürgen. Direito e democracia: entre facticidade e validade. Rio de Janeiro: Tempo Brasileiro, 1997. p. 92.

25 VON SINNER, Rudolf. Teologia pública no Brasil: um primeiro balanço. Perspectiva Teológica, Belo Horizonte, n. 122, p. 11-28, jan./abr. 2012. p. 12.

26 TRACY, David. A imaginação analógica: a teologia cristã e a cultura do pluralismo. Trad. Nélio Schneider. São Leopoldo: Unisinos, 2006. p. 68.

27 CALDAS, Carlos. Desafios da teologia pública para a reflexão teológica na América Latina. Revista de Cultura Teológica, São Paulo, v. 88, p. 328-353, jul./dez. 2016, p. 334. 
fonte e a origem dessa publicidade está no próprio ser de Deus revelado em Jesus Cristo. Assim sendo, baseada no ministério público de Jesus, a teologia em si tem uma inegável dimensão social e profética também na esfera pública.

A dimensão pública da teologia, portanto, partindo da prática de Jesus que falava uma linguagem acessível aos seus interlocutores, procura também se expressar na sua capacidade de traduzir as suas convicções religiosas numa racionalidade acessível à compreensão secular. Sua relevância pública se demonstra, portanto, na capacidade de dialogar com as ciências, culturas e religiões, atenta aos desafios sociais, políticos e econômicos emergentes na sociedade hodierna.

Segundo Moltmann, a teologia é pública não apenas em sua autocompreensão ou aplicação, mas, sobretudo, enquanto ressalta a perspectiva escatológica das coisas públicas, colocando-as sob a luz do Reinado de Deus vindouro. Assim, quando este for verdadeiramente o foco da teologia, as questões em torno das minorias sociais ganharão uma dimensão teológica inexplorada. Para ele, o lugar da teologia não é atrás dos muros dogmáticos ou eclesiásticos, mas no meio dos campos de conflito ${ }^{28}$.

Neste sentido, a teologia fundamental, enquanto dimensão reflexiva e operante dos fundamentos da fé torna-se uma dimensão profética da própria teologia diante das situações de discriminação, marginalização e injustiça. Ela é chamada a empreender sua cidadania pelo diálogo e compromisso em vista de uma sociedade mais justa e solidária. Partindo de uma metodologia contextual, que se fundamenta no âmago da fé, a teologia carrega consigo o intuito de ser pertinente ao debates em torno da elaboração de políticas públicas em prol da diminuição das desigualdades sociais.

Destarte, a teologia precisa ser capaz de dialogar com as instituições públicas a partir de uma visão crítica dos problemas sociais, a fim de contribuir com a cidadania e de pensar em uma sociedade que proporcione um projeto de vida mais integral e humanizado. No espaço público, a preocupação primeira da teologia não deve ser a manutenção do poder eclesiástico. Ela deve primar por princípios aceitos pela coletividade e que exprimam anseios universalizáveis, tais como o amparo aos fracos

28 MOLTMANN, Jürgen. A paixão de Cristo: por uma sociedade sem vítimas. Cadernos IHU em formação, São Leopoldo, p. 78-82, 2008, p. 81. 
e excluídos, o combate à corrupção, critérios mais justos e igualitários e práticas de altruísmo na manutenção da convivência social ${ }^{29}$. Esse deve ser o sentido da fé que procura a sua inteligibilidade.

A teologia não pode limitar sua fala aos públicos eclesiásticos e acadêmicos, mas precisa dialogar com a sociedade, a fim de não cair em um monólogo. Como em todo diálogo, o grande desafio da teologia pública consiste em ouvir a fala da sociedade sem abrir mão do proprium do seu conteúdo, que é o depósito da fé revelada, respeitando sempre a alteridade irredutível dos interlocutores, mas ao mesmo tempo, fazendo ouvir com coragem a sua voz ${ }^{30}$.

\section{Conclusão}

A teologia pública brasileira e latino-americana está dando os seus primeiros passos à procura de referenciais teóricos e delimitações teleológicas. Dialogar humildemente com a sociedade, sem abrir mão de seu conteúdo específico, não é uma tarefa fácil para a teologia. Alguns referenciais teóricos poderão auxiliar a teologia nesse sentido, tais como o pensamento da alteridade de Emmanuel Levinas, o pensamento complexo de Edgar Morin, o pensamento fraco de Gianni Vattimo e o pensamento hermenêutico de Claude Geffré.

Para Levinas, "a filosofia do poder, a ontologia, como filosofia primeira que não questiona o Mesmo, é uma filosofia da injustiça" ${ }^{31}$. A ética da alteridade de Levinas é um antídoto contra o narcisismo e o egoísmo que cega o ser humano para sua corresponsabilidade com seu contexto vital. A perspectiva da alteridade abre as consciências para o horizonte da mútua responsabilidade. Uma teologia que não dá voz ao outro, que não procura ouvir, não pode ser dialógica, e, por tanto, não é pública.

Da mesma forma o paradigma da complexidade de Morin lembra que os saberes são tecidos conjuntamente. "A complexidade não compreende apenas quantidades de unidade e interações que desafiam

29 CARVALHO, Osiel Lourenço de. Religiões no espaço público: reflexões a partir da teologia pública. Correlatio, São Paulo, v. 13, n. 25, p. 105-116, jun. 2014, p. 116.

30 CALDAS, Carlos. Desafios da teologia pública para a reflexão teológica na América Latina. Revista de Cultura Teológica, São Paulo, v. 88, p. 328-353, jul./dez. 2016, p. 343.

31 LEVINAS, Emmanuel. Totalidade e infinito: ensaios sobre a exterioridade. Lisboa: Edições 70, 1977. p. 70. 
nossas possibilidades de cálculo: ela compreende também incertezas, indeterminações, fenômenos aleatórios" ${ }^{32}$. A complexidade se relaciona com o acaso, com o imprevisto, ao contrário de sistemas doutrinários fechados, os quais caracterizariam o pensamento simples. A modernidade fragmentou os saberes, os compartimentando. Segundo Morin, é preciso reagrupar os saberes, fazendo que conversem entre si, a fim de procurar dar conta da realidade.

Por conta da modernidade, Vattimo acredita que há um enfraquecimento das categorias ontológicas tradicionais. Na esteira de Nietzsche e Heidegger, a racionalidade cartesiana está sob julgamento. A teologia moderna, muitas vezes, pretendeu sistematizar a verdade revelada a partir de um dogmatismo absolutista. Este é o pensamento forte criticado por Vattimo. Como uma alternativa a esse modelo, Vattimo propõe o pensamento fraco no sentido de que todo dizer é sempre provisório e está imerso em uma jornada que se distancia cada vez mais da razão dominadora ${ }^{33}$.

De acordo com Vattimo, a verdade que nos torna livres, conforme foi anunciada por Jesus, não é a verdade objetiva das ciências, nem mesmo a verdade metafísica dos manuais de teologia, mas sim, a verdade do amor, a qual é um apelo prático ${ }^{34}$. A teologia na esfera pública precisa estar consciente de seus limites, a fim de rejeitar o fundamentalismo racionalista que pretende dar resposta para tudo, e para que seja capaz de uma leitura mais profunda dos textos bíblicos e dos dogmas cristãos dialogando com outras confissões religiosas e com a sociedade secular ${ }^{35}$. O pensamento fraco ajuda a ver a teologia como um fazer provisório e questionável, a serviço do bem comum.

O pensamento hermenêutico de Geffré concebe o pluralismo cultural e religioso atual como uma oportunidade que convida "a reinterpretar

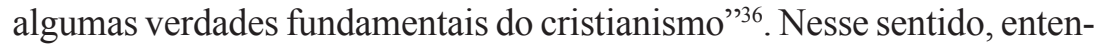

32 MORIN, Edgar. Introdução ao pensamento complexo. 3. ed. Porto Alegre: Sulina, 2007. p. 35.

33 VATTIMO, Gianni; ROVATTI, Pier Aldo. II pensiero debole. 3. ed. Milano: Giangiacomo Editore, 1985. p. 10.

34 VATTIMO, Gianni. A idade da interpretação. In: RORTY, Richard; VATTIMO, Gianni. O futuro da religião: solidariedade, caridade, ironia. Organização Santiago Zabala. Rio de Janeiro: Relume Dumará, 2006. p. 71.

35 VATTIMO, Gianni. Depois da cristandade: por um cristianismo não religioso. Rio de Janeiro: Record, 2004. p. 64.

36 GEFFRÉ, Claude. Crer e interpretar: a virada hermenêutica da teologia. Trad. Lúcia M. Endlich Orth. Petrópolis: Vozes, 2004. p. 131. 
de que "os cristãos são, por pura graça, as testemunhas da revelação que lhes foi confiada por Jesus Cristo, mas não são seus proprietários" ${ }^{" 37}$. $\mathrm{O}$ teólogo hermeneuta se dá conta de que "não há mais condições de uma perspectiva de entrincheiramento, de fixação num único itinerário" ${ }^{38}$, na esfera pública.

É preciso interpretar os fundamentos da fé de maneira nova, operar de forma criativa, superando o paradigma da reprodução, a fim de que sob a iluminação do Espírito, se consiga dar uma resposta relevante aos anseios mais profundos dos homens de hoje ${ }^{39}$. A teologia tem a missão profética de "atualizar e tornar pertinente para a contemporaneidade a mensagem da Revelação"40, superando "toda pretensão insustentável de totalização monopolizadora da verdade" ${ }^{41}$, através de uma postura dialógica e empática.

Com senso crítico, a teologia precisa articular-se em três níveis no contexto atual: em nível macro, a teologia como um discurso entre outros, precisa saber conviver com essa realidade, devido ao fato de que não há mais uma função integradora do discurso teológico diante da sociedade e da cultura; em nível médio, a relevância da teologia emerge de seu potencial ético e antropológico, e por isso, ainda tem alguma pertinência como serviço à sociedade; a questão mais problemática se encontra em nível micro, pois conceitos teológicos muito elementares, outrora impregnados no cotidiano da cultura ocidental, tornam-se cada vez mais indecifráveis para as pessoas de hoje.

Nesse sentido, o teólogo precisa cumprir a sua função hermenêutica enquanto mediador entre a linguagem religiosa e a linguagem secular, influindo decididamente na formação de uma conduta autônoma, comunicativa e comprometida dos sujeitos de fé, engajados em uma sociedade

37 GEFFRÉ, Claude. De Babel à Pentecostes: ensaios de teologia inter-religiosa. Trad. Margarida Maria Cichelli Oliva. São Paulo: Paulus, 2013. p. 61.

38 TEIXEIRA, Faustino. Teologia das religiões: uma visão panorâmica. São Paulo: Paulinas, 1995. p. 188.

39 GEFFRÉ, Claude. Como fazer teologia hoje: hermenêutica teológica. Trad. Benôni Lemos. São Paulo: Paulinas, 1989. p. 270.

40 GOMES, Tiago De Fraga. A teologia hermenêutica de Claude Geffré e a sua relevância para a teologia da revelação. 2015. 140 f. Dissertação (Mestrado em Teologia) - Faculdade de Teologia, Pontifícia Universidade Católica do Rio Grande do Sul, Porto Alegre, 2015b, p. 13.

41 GOMES, Tiago de Fraga. A economia do Verbo encarnado e o diálogo entre as religiões em Claude Geffré. Encontros Teológicos, Florianópolis, v. 31, n. 2, p. 309-326, maio/ago, 2016, p. 310. 
extremamente capitalista, individualista e instrumental - que sacraliza a produtividade, idolatra o dinheiro e coisifica o ser humano, concebendo-o como homo oeconomicus -, a fim de fundamentar uma reflexão que pensa a humanidade em termos de intersubjetividade não-funcional, que não planeja tudo em termos de custo-benefício, mas que responda adequadamente aos mecanismos de exploração e exclusão atualmente vigentes, tendo em conta a necessidade de relações de cuidado, de mútua responsabilidade e de gratuidade, e convidando para a discussão e a formação de opiniões acerca de assuntos pertinentes a todos, com o intuito de provocar uma ação transformadora em prol do bem comum.

\section{Referências bibliográficas}

ALFARO, Juan. De la cuestión del Hombre a la cuestión de Dios. Salamanca: Sigueme, 1989.

BÍBLIA. Português. A Bíblia de Jerusalém. Nova edição rev. e ampl. São Paulo: Paulus, 2004.

BOFF, Clodovis. Teoria do método teológico. São Paulo: Vozes, 1998.

CALDAS, Carlos. Desafios da teologia pública para a reflexão teológica na América Latina. Revista de Cultura Teológica, São Paulo, v. 88, p. 328-353, jul./dez. 2016.

CARVALHO, Osiel Lourenço de. Religiões no espaço público: reflexões a partir da teologia pública. Correlatio, São Paulo, v. 13, n. 25, p. 105116, jun. 2014.

CONCÍLIO VATICANO II, 1962-1965, Cidade do Vaticano. Dei Verbum. In VIER, Frederico (Coord. Geral). Compêndio do Concílio Vaticano II. 29. ed. Petrópolis: Vozes, 2000. p. 121-139.

. Gaudium et Spes. In VIER, Frederico (Coord. Geral). Compêndio do Concílio Vaticano II. 29. ed. Petrópolis: Vozes, 2000. p. 143-256.

DENZINGER, Heinrich; HÜNERMANN, Peter. Compêndio dos símbolos, definições e declarações de fé e moral. Trad. José Marino Luz. São Paulo: Paulinas; Loyola, 2007.

GEFFRÉ, Claude. Como fazer teologia hoje: hermenêutica teológica. Trad. Benôni Lemos. São Paulo: Paulinas, 1989.

. Crer e interpretar: a virada hermenêutica da teologia. Trad.

Lúcia M. Endlich Orth. Petrópolis: Vozes, 2004. 
. De Babel à Pentecostes: ensaios de teologia inter-religiosa. Trad. Margarida Maria Cichelli Oliva. São Paulo: Paulus, 2013.

GOMES, Tiago de Fraga. A eclesiologia conciliar na América Latina: a comunhão gera a missão. Porto Alegre: Editora Fi, 2015 a.

. A teologia hermenêutica de Claude Geffré e a sua relevância para a teologia da revelação. 2015. 140 f. Dissertação (Mestrado em Teologia) - Faculdade de Teologia, Pontifícia Universidade Católica do Rio Grande do Sul, Porto Alegre, 2015b.

. A economia do Verbo encarnado e o diálogo entre as religiões em Claude Geffré. Encontros Teológicos, Florianópolis, v. 31, n. 2, p. 309-326, maio/ago. 2016.

. Por uma relação entre inteligência da fé e racionalidade científica no contexto atual. Encontros Teológicos, Florianópolis, v. 32, n. 1, p. 121-138, jan./abr. 2017.

GRÜMME, Bernhard. Fé impossivel?: questionamentos das ciências, da economia, da sociedade e da cultura. Subsídios do Seminário Intensivo de Teologia Pública. Porto Alegre: PUCRS, 2017a.

. Um conceito não-simultâneo da liberdade: liberdade liberada. Subsídios do Seminário Intensivo de Teologia Pública. Porto Alegre: PUCRS, 2017b.

. Uma época sem religião: pluralismo e secularização. Subsídios do Seminário Intensivo de Teologia Pública. Porto Alegre: PUCRS, $2017 \mathrm{c}$.

. Religião e fé como realização do ser humano: aproximações antropológicas nas condições da modernidade tardia. Subsídios do Seminário Intensivo de Teologia Pública. Porto Alegre: PUCRS, 2017d.

HABERMAS, Jürgen. Direito e democracia: entre facticidade e validade. Rio de Janeiro: Tempo Brasileiro, 1997.

JOÃO XXIII, Papa. Discurso de sua Santidade Papa João XXIII na abertura solene do Ss. Concílio, Roma, 1962. Disponível em: $<\mathrm{https} / /$ w2.vatican.va/content/john-xxiii/pt/speeches/1962/documents/hf j-xxiii_spe_19621011_opening-council.html>.Acesso em: 30 maio 2017. LEVINAS, Emmanuel. Totalidade e infinito: ensaios sobre a exterioridade. Lisboa: Edições 70, 1977. 
LIBANIO, João Batista. Eu creio nós cremos: tratado da fé. São Paulo: Loyola, 2000.

MOLTMANN, Jürgen. A paixão de Cristo: por uma sociedade sem vítimas. Cadernos IHU em formação, São Leopoldo, p. 78-82, 2008.

MORIN, Edgar. Introdução ao pensamento complexo. 3. ed. Porto Alegre: Sulina, 2007.

MOUNIER, Emmanuel. Quando a cristandade morre. Rio de Janeiro: Paz e Terra, 1972.

TEIXEIRA, Faustino. Teologia das religiões: uma visão panorâmica. São Paulo: Paulinas, 1995.

TRACY, David. A imaginação analógica: a teologia cristã e a cultura do pluralismo. Trad. Nélio Schneider. São Leopoldo: Unisinos, 2006.

VATTIMO, Gianni. A idade da interpretação. In: RORTY, Richard; VATTIMO, Gianni. O futuro da religião: solidariedade, caridade, ironia. Organização Santiago Zabala. Rio de Janeiro: Relume Dumará, 2006.

. Depois da cristandade: por um cristianismo não religioso. Rio de Janeiro: Record, 2004.

; ROVATTI, Pier Aldo. Il pensiero debole. 3. ed. Milano: Giangiacomo Editore, 1985.

VON SINNER, Rudolf. Teologia pública no Brasil: um primeiro balanço. Perspectiva Teológica, Belo Horizonte, n. 122, p. 11-28, jan./abr. 2012. 